\title{
THE MANAGEMENT METHOD PREVENTING A CRISIS SITUATION IN AN ELECTRICAL ENERGY UTILITY
}

\author{
Krzysztof MAJ*, Tadeusz KRUPA** \\ *Industrial Electric Power Laboratory \\ Practical Training Centre, ul. Sportowa 13, 26-670 Pionki \\ email: kmp@poczta.onet.pl \\ **Faculty of Management \\ Warsaw University of Technology, ul. Narbutta 85, 02-524 Warsaw \\ email: t.krupa@wz.pw.edu.pl
}

\begin{abstract}
The trend observed in the past few years, aiming at raising the level of energy safety both in Poland and in the world, has changed irreversibly the management specificity in the electrical energy industry. Traditional methods of management in this sector began to be insufficient in relation to the present quickly changing reality. The article presents a concept of the management method preventing a crisis situation in an electrical energy utility - a baseload power plant for the risks: a power unit overloading resulting in its disorderly close-down, a lack of technical-economic data transmission and a modification of business data.
\end{abstract}

Key words: management method, electrical energy utility, baseload power plant, crisis situation, artificial intelligence, Kohonen risk map.

1

Introduction

At present electrical energy belongs to the key products, which are determined with the name of "the products - representatives". From the economic point of view the quantity of electrical energy production is the measurement of the industrialization of a certain country, its competitiveness on the world markets, determining at the same time the standard of a society's life. It is impossible to imagine a contemporary economy, which is not based on electrical energy. Electrical energy has a lot of advantages, the most important of which are: an easiness of transformation into other types of energy (mechanical, chemical, radial, thermal), an easiness of transmission to practically unlimited distances, a simple division among customers, an immediate readiness of usage, the purity of processes of its processing and electrical energy transformation, both in industry and household. Other branches and crafts of the national economy are dependent on the energy sector, among which worth mentioning are: the metallurgical industry, the chemical industry, telephony, radio-technology, television, industrial electronics, automatics, robotics, and calculation technology and information technology science - the most strictly connected with the energy sector. Concluding, one may say that there is no branch of life, where the contribution of electrical energy would not be noticed.
Assessments in the electrical energy statistics say that $8,3 \mathrm{mln} \mathrm{GWh}$ of electrical energy was produced in the world in 1980, 11,7 mln GWh in 1990, 15,0 mln GWh in 2000 and in 2006 over $17 \mathrm{mln}$ GWh of electrical energy was produced. The biggest share in its production belonged to the USA $-23 \%$ of the total world production, China $-14,2 \%$, Japan - 5,7\%, Russia $5,5 \%$, India $3,6 \%$, Canada $-3,3 \%$, Germany $-3,2 \%$, France $-3,1 \%{ }^{1}$.

The share of Poland in the total world production is estimated at approximate $0,82 \%$, which gives it 22 nd place in the world. It is important to emphasize that this share for Poland amounted to $1,2 \%$ in 1999.

Analysts in the energy branch estimate that in 2020 the demand for electrical energy will reach the value 27 $\mathrm{mln}$ GWh. This fact is explained by a dynamic development of the world economy, population growth, a rise in their income and progressive urbanization. A higher demand for electrical energy causes more and more frequently a situation of deficiency in supply of the goods. The problem lies in the impossibility of its storage because this commodity is produced as "in statu nascendi". More and more crisis situations, which are various in their nature, occur as a result of inadequacy of the rate of demand growth and production possibilities of the plants responsible for the

\footnotetext{
${ }^{1}$ The data come from CIA World Factbook January 2009.
} 
production of this good. These situations violate the energy safety both on the scale of a particular country and of the world.

With regard to such a situation, there appears a problem of a rational energy management related to both its production and usage. As a characteristic feature of electrical energy produced by power plants is a lack of possibility of its storage, therefore power plants producing it at the same time, working simultaneously in The National Power Grid [Krajowy System Elektroenergetyczny (KSE)], which is part of a European grid, have to adjust their load to the changes of the demand on power in this grid. Thus, we may say that on one hand there is a constant forcing of a power plant to work through the demand on energy by its customers connected to power grids and on the other hand, consumers may draw at one time such power as may be produced by power plants. Even an instantaneous cutoff of energy for its customers may cause particular economic loss and therefore a high reliability of the whole grid is required ([2], p.126). The above mentioned power grid consists of entities responsible for electrical energy production (baseload power plants), entities responsible for electrical energy transmission (in Poland the responsible entity is PSE Operator S.A.) and consumers - customers of electrical energy. The operator of the industrial system coordinates a proper functioning of the electrical energy market keeping the balance between the demand and supply.

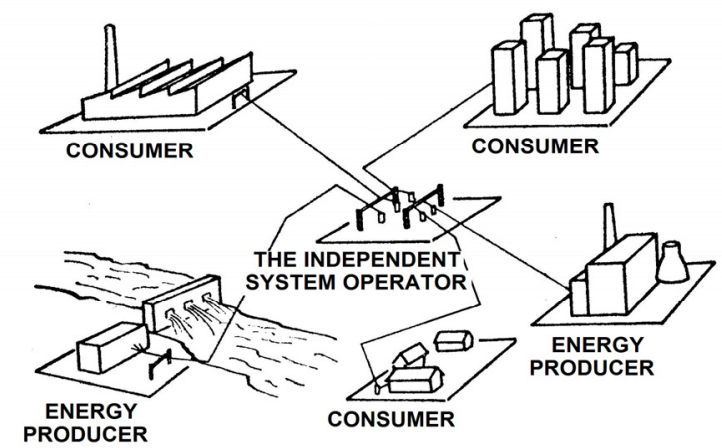

Figure 1. Pictorial model of The National Power Grid

The basic element of technical infrastructure in power plants, being responsible for production of electrical energy are power units. From the economic point of view, turbogenerators processing thermal energy are of the greatest significance in electrical energy grid, and this energy in case of the power plant working in The National Power Grid [KSE], is mainly obtained from burning mineral and brown coal. The percentage share of this type of power plant in production of elec- trical energy is estimated on the level of $92 \%$. To drive the turbine of a turbogenerator, water steam is used, which has specified thermo-dynamic parameters and which is generated in steam boilers, which are the elements of electrical energy turbogenerators. Then the kinetic energy in a turbogenerator is processed, owing to electro-magnetic effects, into electrical energy.

The possibility of an uninterrupted transfer of electrical energy between its manufacturers (producers) and customers (consumers), on the assumption that the demand and supply are balanced, at economically justified prices, is a fundamental condition of The National Market of Electrical Energy [KREE- Krajowy Rynek Energii Elektrycznej] functioning. From the point of view of the national economy the changeability of the demand on electrical energy, its immaterial shape, and a lack of possibility of its storage make for the factors causing serious economic repercussions in the energy trade, contributing to substantial fluctuations in prices. Apart from the energy itself, the service of its transmission from producers to customers is a subject of trade on the electrical energy.

\section{System of information exchange between the subjects on the electrical energy market and energy safety}

The model of the electrical energy market in Poland is presented in Figure 2. Arrows indicate information exchange between its entities.

Groups of entities function on The National Market of Electrical Energy, among which there are the following electrical energy utilities:

- energy producers (professional baseload power plants),

- entities exploiting the transmission power grid (with capacity of $220 \mathrm{kV}$ and $400 \mathrm{kV}$ ),

- entities exploiting the distribution power grid (with capacity of $110 \mathrm{kV}$ and lower),

- entities dealing with the energy trade.

With regard to the form of trade, the energy market in Poland is divided into the following types of markets ${ }^{2}$ :

- Contract Market,

- Stock Market,

- Balancing Market,

- Power Exchange.

\footnotetext{
${ }^{2}$ You will find futher information on the electrical energy market in items [14] i [15] and on the website: www.cire.pl.
} 


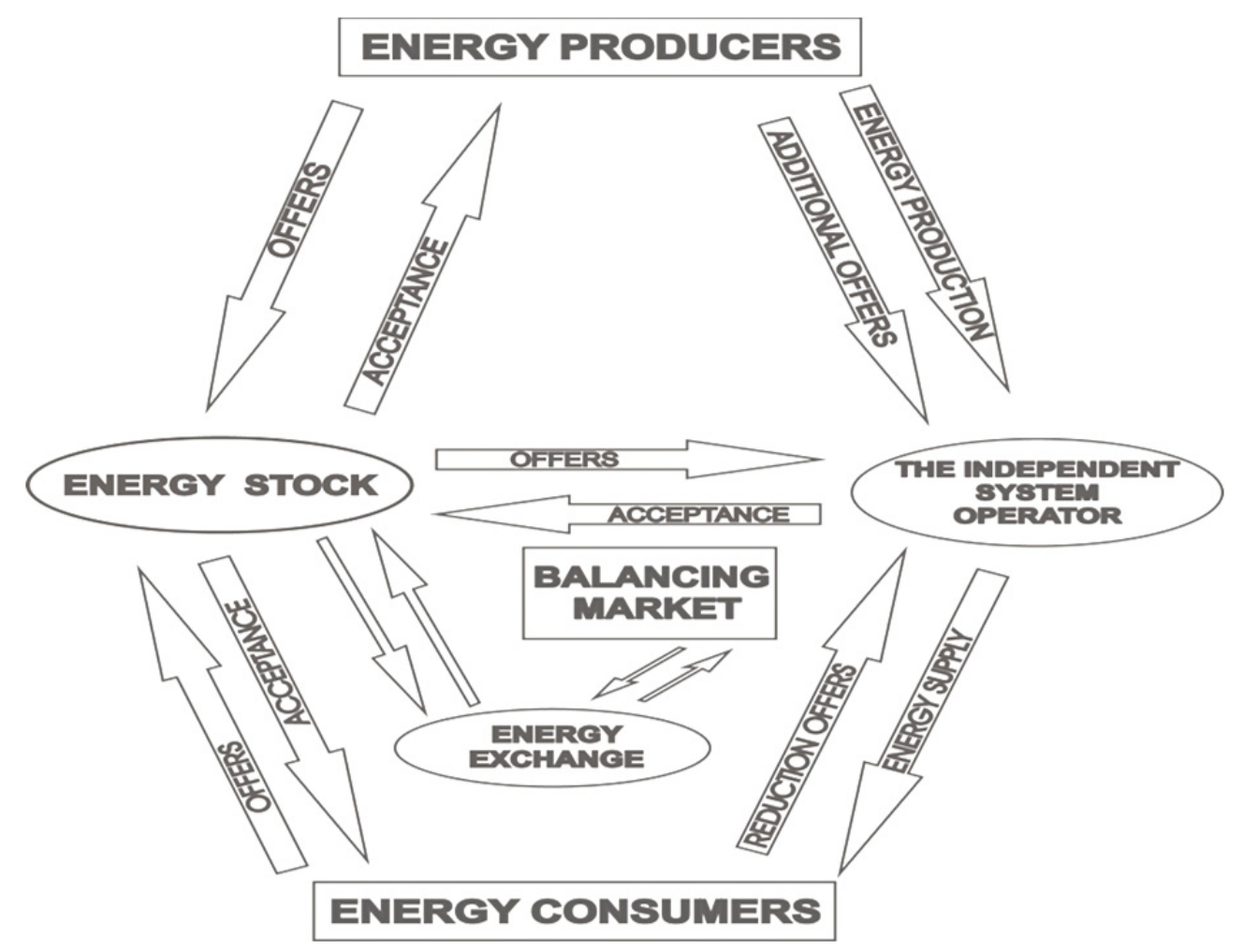

Figure 2. System of information exchange between the entities of the electrical energy market (source: self study with the use of [15])

An effective functioning of the whole market of electrical energy, consisting in an appropriate balancing of the demand and supply of energy at the maintenance of competition mechanisms, an efficient Exchange of information between the market participants and especially its most important segment - the Balancing Market, is conditioned by the reliability of technical infrastructure, which consist of, apart from hardware, advanced information technology systems: calculationmeasuring and telecommunications, being used to exchange data of technical-trading type (e.g. coordination plans, purchase and sales offers and acceptances).

The basic task of information technology solutions for the electrical energy industry is to provide correct and reliable information at the proper time between the participants of The National Market of Electrical Energy. It has been declared that the priority for the projecting and implementing of these information technology systems is the stability of The National Market of Electrical Energy in Poland, as well as integrity of the transmission grid and the reliability of the quality of electrical energy supply, which finally secures energy safety of the whole country.

The correct communication and business information exchange between the participants of the electrical energy market is provided by the Internet, the public telecommunication network, the cell telephone network and specialized information and communication technology systems allocated exclusively for the electrical energy industry needs, based on dedicated telecommunication channels. Telecommunication services for the needs of the electrical energy industry in the form of outsourcing are dealt with by TEL-Energo S.A. Appropriate security protocols are used for the transmission of trade information. There is a special information technology system used for this purpose, which supports technical and trade processes on the Balancing Market, being an integrated environment of function modules, which support particular functions of the administrator of this system. The factor integrating the environment is the data bases implemented on the basis of RDBS ORACLE 8I and mechanisms of exchange and registration of electronic documents in the file of XML. The Independent System Operator ${ }^{3}$ [OSPOperator Systemu Przesyłowego] communicates with the participants of the Balancing Market by two systems of information transmission: The System of Operative Cooperation with Power Plants [pol. SOWESystem Operatywnej Współpracy z Elektrowniami] and The Market Information Exchage [pol. WIRE Wymiana Informacji Rynku Energii].

\footnotetext{
${ }^{3}$ PSE Operator S.A. - Polish Transmission System Operator.
} 
The System of Operative Cooperation with Power Plants is an essential element of the technical infrastructure of the electrical energy market. This system enables a confidential exchange of technical information between OSP and power plants in the scope of the market control. The other information is transmitted through a separate channel with the use of WIRE system. The solution of SOWE- WIRE provides an opportunity of automatic information and connecting with automatic units control [17]. The solution of the system of information exchange basing on SOWE and WIRE systems is presented in Figure 3.

The exchange of information between applications takes place in the star topology, i.e. communication is possible only between the central server of OSP, regional and local servers in power plants.

It may be stated without hesitation that the basic task of technical solutions for the electrical energy industry, supported by economic-legal instruments, is providing, within a strictly determined time, reliable information between the participants of The National Market of Electrical Energy.

In the light of the above deliberations, the priority of projecting and implementation of information technology systems is: the stability of The National Power Grid in Poland, integrity of the transmission grid, reliability of the production of electrical energy by power plants and delivery of energy to customers at economically justified prices. The proper implementation of these priorities secures energy safety of the country.

The results of such undertaken actions found their reflection in the document "The Energy Policy of Poland until the Year 2025" accepted by The Ministers Board on 4 January 2005. In this document energy safety is defined as: "the condition of the economy enabling the cover of the current and prospective demand of customers for fuel and energy, in a way technically and economically justified, at minimalization of negative influence of the energy sector on the environment and conditions of the life of society".

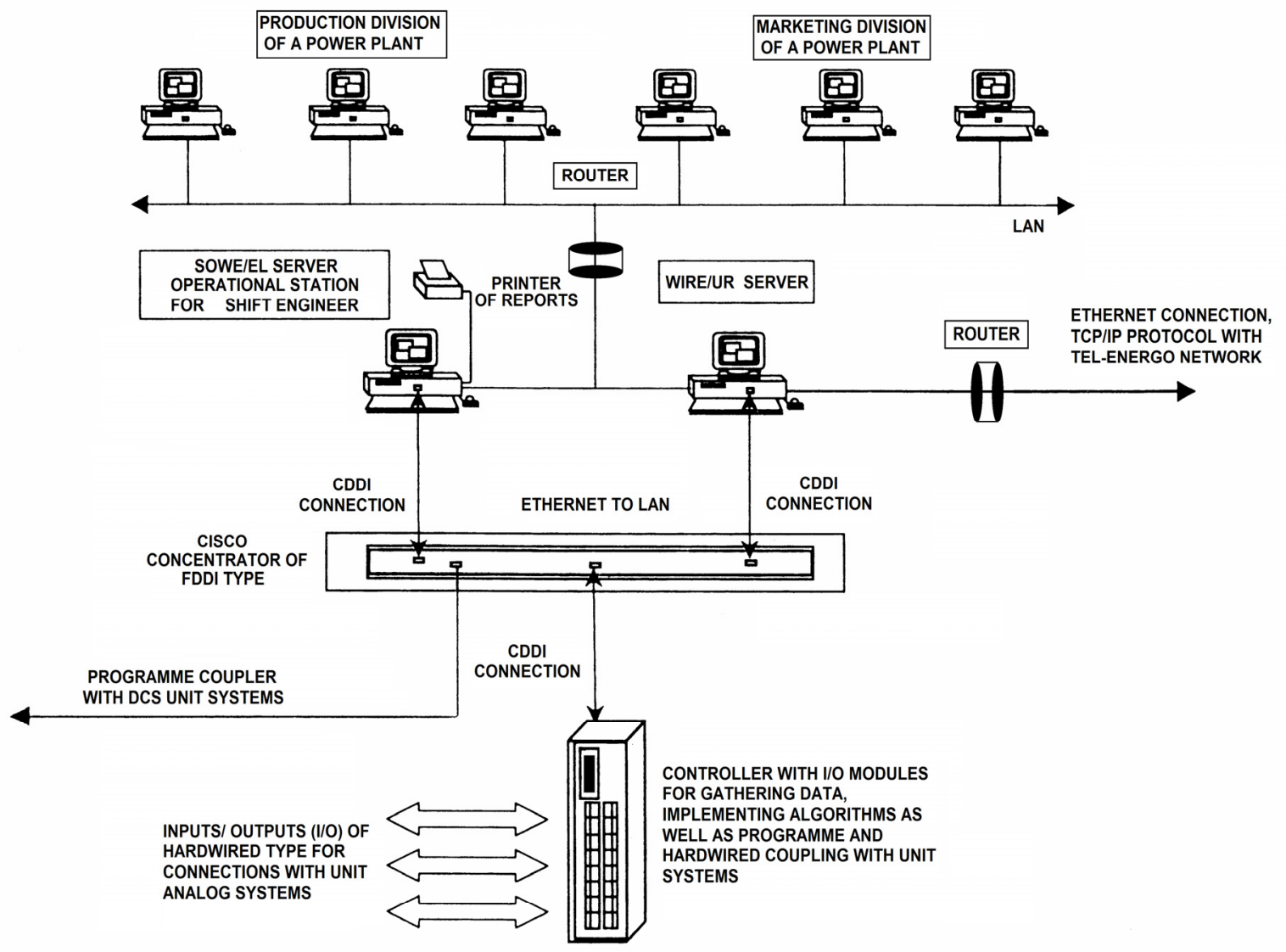

Figure 3. The System of information transmission for the needs of the Energy Market (source: Elektrownia ,KOZIENICE” S.A.) 
In "technical plane" the safety is defined as the ability of the electrical energy systems to survive of sudden breakdowns, such as short-circuits or unpredicted loss of the system elements, including congestion and the system ability to maintain work of regulating areas joint synchronically and avoidance of occurrence of an uncontrolled division of the synchronic area as the effect of a system breakdown [16].

The reliability of electrical energy supply to customers, which is a derivative of the electrical energy safety, is influenced by the sufficiency understood as the ability of an electrical energy system to supply, on the scale of the whole system, the required quantity of capacity and power to customers, with consideration of the abilities of generating sources, transmission capacity

of power grid elements, nodal tensive limitations as well as planned and unplanned elements go-out.

It should be emphasised here that despite the advanced technical solutions and information technology solutions responsible for the correct functioning of the whole the electrical energy system as well as properly oriented state policy, there are a lot of dangers leading to destabilization of the electrical energy market, which directly affect the market entities. For the needs of the article, the considerations will be concentrated around one of the market entities, an electrical energy utility baseload power plant working in The National Power Grid.

\section{Sources of probable crisis situations in an electrical energy utility}

In the subject literature a crisis situation is defined as the result of unplanned events interrupting or threatening the normal functioning of a utility [11].

Research of the subject literature and analyses of the biggest grid breakdowns that have existed in the world allow on multi-plane classification of possible crisis situations, at the risk of which electrical energy utilities may occur.

It should be emphasised here that power plants have different vulnerability and susceptibility to possible crisis situations. It cannot be said unambiguously that a specific crisis situation affects all power plants working in the National Power Grid in the same way. With regard to the research conducted in the baseload power plant, further considerations will concern a crisis situation common for a lot of power plants in Poland, caused by the danger of power units overloading resulting in disorderly close-down, a lack of technicaleconomic data transmission essential for business processes in a utility and a modification of business data.

The risk of different situations occurring in power plants forces them to take new measures aimed at increasing the reliability of electrical energy production. Crisis management has become a process deeply set in the activity of electrical energy utilities, appearing to be insufficient and too expensive for many power plants.

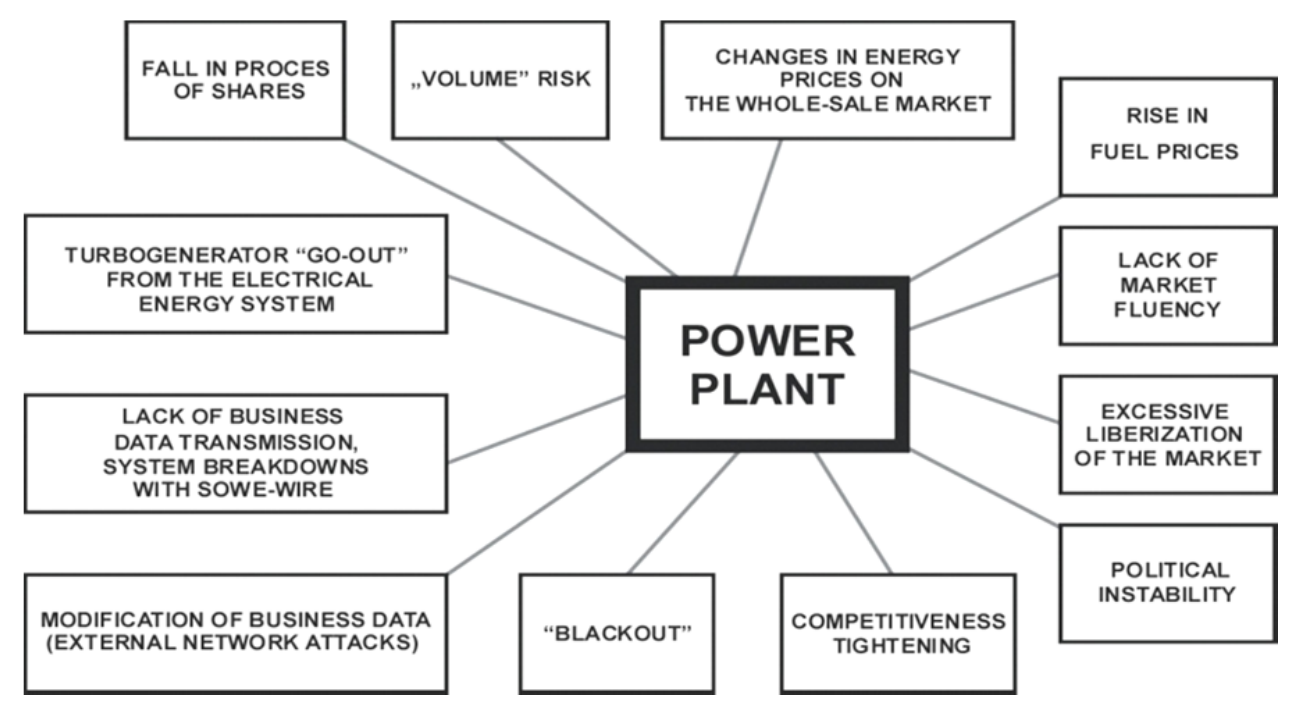

Figure 4. Sources of possible crisis situations

(source: own study with the use of [5])

The burden of actions undertaken should be concentrated on seeking such anti-crisis management meth- ods as would allow foreseeing the symptoms of a coming crisis in time so that it would not esca- 
late. It should be emphasised that interference in the working continuity of the National Power Grid or a substantial part of it makes potentially the most serious interference for the functioning of the technical infrastructure of the country, for which it is difficult to foresee the economic and social effects, which in consequence leads to a violation of the state energy safety.

We may mention here the famous "California Syndrome" (2000/2001), which ended with a breakdown of the electrical energy market in California. The California syndrome (also called purposely a California Lesson) made the decision-makers realize how factors appearing trivial (e.g. a temperature rise, stricter ecological norms, wrong legal regulations) contributed to a lot of events with disastrous effects. As a result of lack of organized actions and methods, aiming at identification of key dangers connected with an existed crisis situation, it led to loss estimated at approximately $\$ 12$ milliard.

As the market surveys and analysis of breakdowns in Poland and in the world show, the most disastrous situation for each power plant is a situation of a turbogenerator go-out (go-out of a power unit) from the electrical energy system. A turbogenerator is understood as a set of devises used to generate electrical energy (also called a turbogenerator or a turboset).

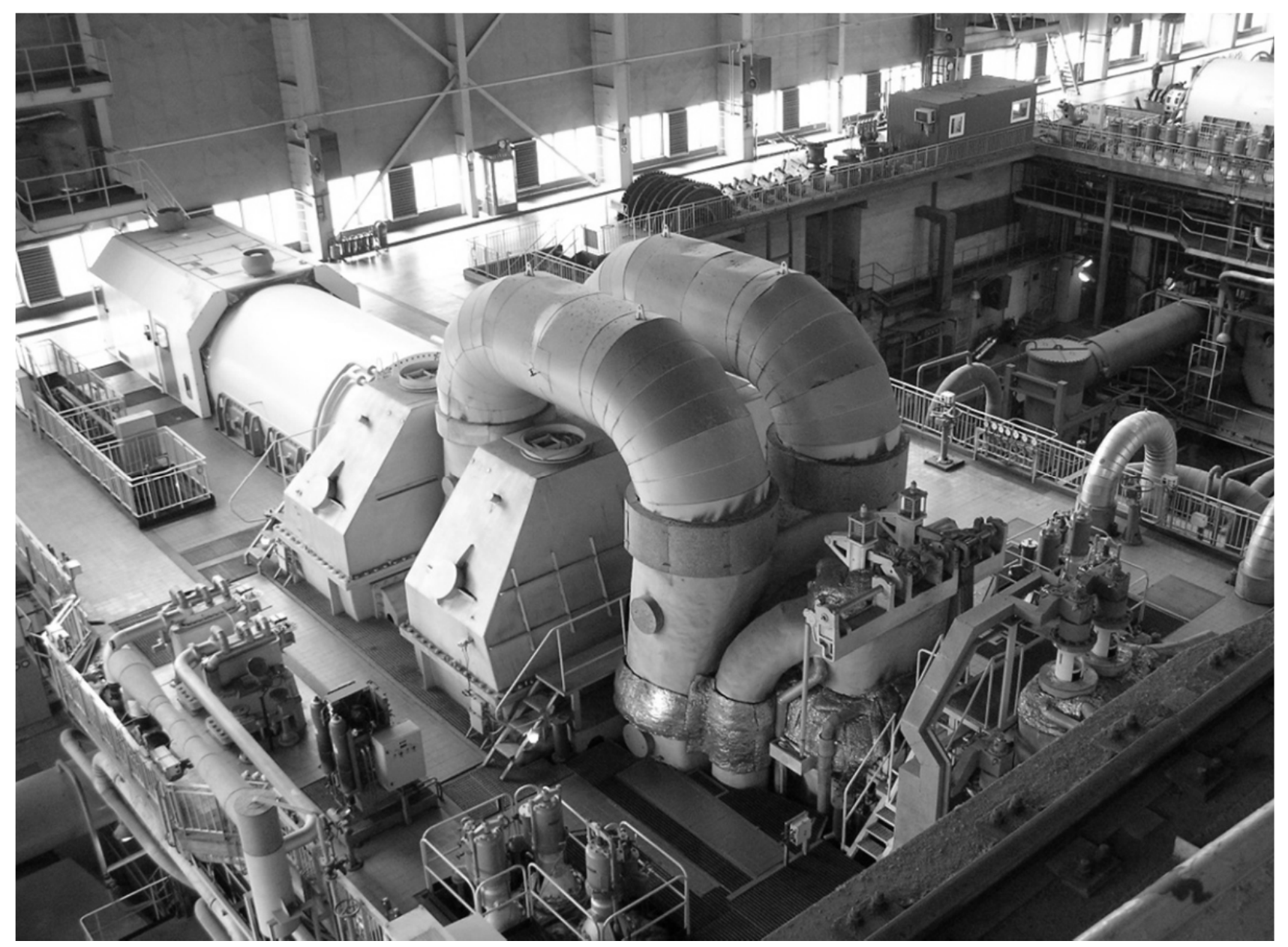

Figure 5. The object of study - a turbogenerator (turbogenerator with the capacity of $500 \mathrm{MW}$ ) responsible for producing electrical energy ${ }^{4}$

(source: photo by Elektrownia ,KOZIENICE” S.A.)

\footnotetext{
${ }^{4}$ Simplifying, we may accept that a turbogenerator with a steam boiler and the entire necessary technical infrastructure are called a power unit.
} 


\section{Economic dimension of a crisis situation} as a justification of research on the issue

A turbogenerator go-out from the system may be caused by its purposeful disconnection because of its substantial overloading (action of sets protecting a turbogenerator from its destruction, the so called protection automatics) or on a clear order issued by Power Dispatch Center (pol. Krajowa Dyspozycja Mocy - KDM) ${ }^{5}$. As an example, we may follow the crisis situation that took place on 26 June 2006 in KSE [The National Power Grid] [16]:

„... since the early hours of the morning (around 10:00 a. m.), voltage drops in the transmission and distribution grids had been observed. About 12:00 there were symptoms of danger of voltage maintenance in nodes within the maximum quantity. After 1:00 p. m. sudden events took place, the effects of which caused go-out of turbogenerators from the grid. In Ostrołęka power plant because of a grid overloading at 1:07:57 p.m. the voltage on the switching station buses $110 \mathrm{kV}$ declined to the value of $101 \mathrm{kV}$, while on the switching station buses $220 \mathrm{kV}$ it decreased to $177,9 \mathrm{kV}$. At 1:08 p.m. there was a self-activating disconnection of two power units and the cable to Sweden. At 1:00 p.m. in Power Station "Kozienice" the active power of Power Unit no. 7 increased from $218 \mathrm{MW}$ to $224 \mathrm{MW}$. At 1:09 p.m. there was a self-activating disconnection of the power unit and the turbogenerator. At 1:09 p.m. because of low voltage there was a disconnection of two power units in Białystok thermal-electric power plant. At 1:12 p.m. as a result of the activity of the under-voltage protection, there was a disconnection of three power units in Starachowice thermal-electric power plant and at 1:13 p.m. the was a disconnection of the cable to Sweden. Because of a deficiency of power and very low voltage some customers in north-east Poland were cut off. Crisis situations also affected Warsaw to a great extent. At about 4 p.m. the normal functioning of the transmission system was resumed."

It is appropriate to raise the economic aspect of the appraisal of crisis situation effects. It should be emphasised that it is the most difficult phase of post-crisis actions. We cannot evaluate unambiguously and precisely the losses that were borne by electrical energy

\footnotetext{
${ }^{5}$ The process of a generator switching-off from KSE is described in detail by relevant instructions and procedures, discussion of which goes beyond the subject of the article. An interested reader may find them on websites www.ure.gov.pl, www.pse.pl and [17].
}

customers because of a disconnection in energy supply. Operator Systemu Przesyłowego [The Independent System Operator] did not balance the energy market properly. Power plants, bound by different contracts and agreements concerning electrical energy sale, did not fulfil those agreements.

We may come across a lot of models in the subject literature, which allow us in a more or less precise way, to evaluate the costs of a past crisis situation. However, these models do not have a universal feature. Too big a number of exogenous variables and the individual character of a crisis situation make the use of these models limited. Knowing a 24 hour schedule of overloadings of a specified turbogenerator, the price of $1 \mathrm{MWh}$ of produced electrical energy, the day of the week and the season (e. g. a work day, 26th August, the emergency time 24h), simulation studies were conducted, the purpose of which was to project the economic dimensions of the effects of this crisis. For such variables, losses burdened by the power plant only on account of unproduced energy because of a go-out of one power unit with capacity $500 \mathrm{MW}$, may be evaluated for PLN $1795032^{6}$. Experts in the electrical energy field estimate that these costs may be even hundreds times higher than the value of unproduced energy ${ }^{7}$.

Literature and factographic analysis reveals a substantial shortage of publications and research in the area of the issue under discussion ${ }^{8}$. On one hand an available subject literature raising the issue of crises situations in utilities (seldom in electrical energy ones) concerns exclusively their economic plane (financial crisis), on the other hand, in available studies and conducted research it was mainly concentrated on models predicting a risk of a crisis situation occurring in utilities without an analysis of the causes of this phenomenon. This research mainly concerned crisis situations,

\footnotetext{
${ }^{6}$ All the research and simulation trials were conducted on original measuring data from POWER UNIT $500 \mathrm{MW}$, of Elektrownia „KOZIENICE” S.A., by courtesy of the power plant Authorities.

${ }^{7}$ Gładyś H., Matla R. - Praca elektrowni w SE, WNT, Warszawa 1999, p. 170.

${ }^{8}$ After a serious voltage breakdown that took place on 26 June 2006 in KSE, Instytut Automatyki Systemów Energetycznych [The Institute of Energetic Systems Automatics] in Wrocław started research on such types of crisis situations in power plants. However, this research concerned the issues connected with unreliability of technical devices, rather than prediction of crisis situations.
} 


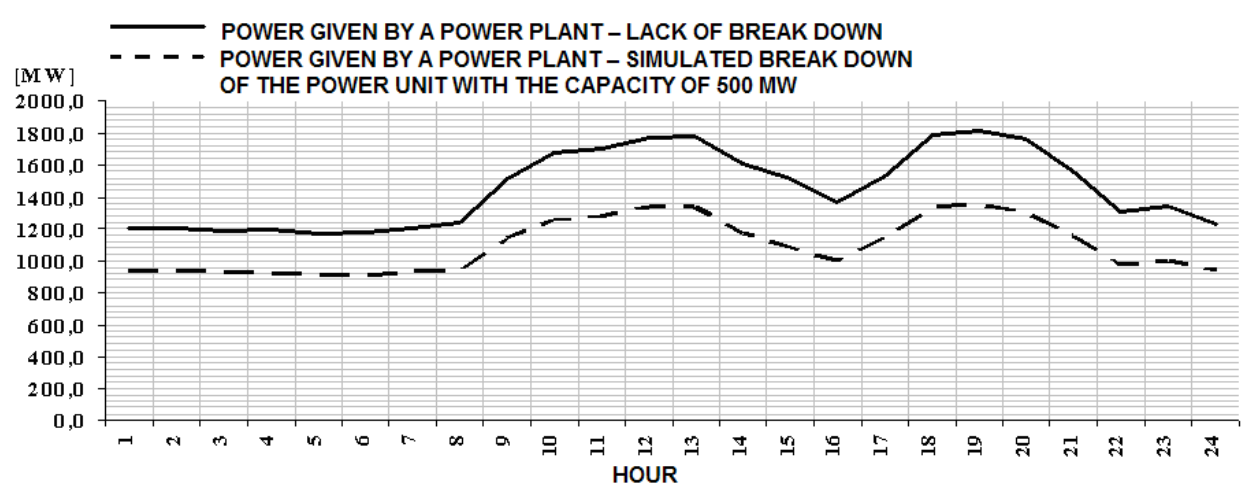

Data: work day, 4th February 2010, price PLN 180.00 for $1 \mathrm{MWh}$, losses amount to PLN 1558330 (approximately € 378235)

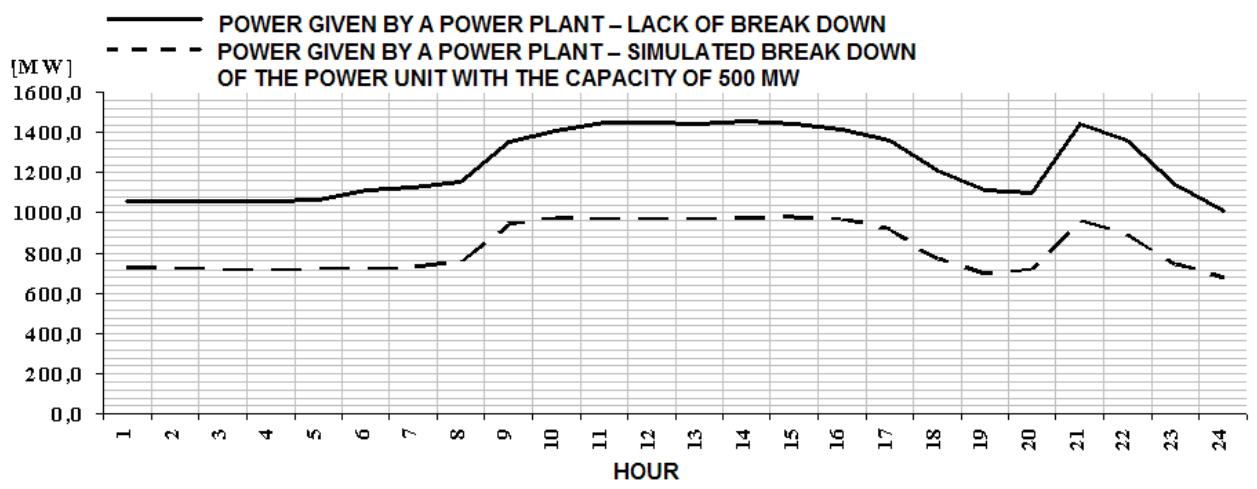

Data: work day, 26 August 2009, price PLN 181.00 for $1 \mathrm{MWh}$, losses amount to PLN 1795032 (approximately € 435687)

Figure 6. Simulation of a crisis situation, go-out of the power unit $500 \mathrm{MW}$, for different input parameters - estimation of losses suffered by the power plant (source: self study)

the sources of which were economic perturbations, bad economic situation etc.

We cannot then talk about an effective usefulness of these studies to solve the issue. A serious impediment in making decisions in the conditions of a crisis situation is a shortage of applicative dimensions of research. Such a condition causes that even well elaborated models are not adequate tools in supporting a management decision in the phases of predicting crisis situations in electrical energy utilities.

On the basis on literature and factographic analysis, related to the state of knowledge in the scope of the issue, we may form the following conclusion, supporting the purposefulness of continuing research in this field:

- professional the electrical energy industry in Poland begins to face requirements difficult to fulfil, which go beyond its current technical and economic opportunities,

- there exist a lot of dangers of the destabilization of the electrical energy market, which create a big risk of activity towards the market entities; these dangers usually lead to crisis situations,

- we may suppose that crises situations will take place in electrical energy utilities with a higher frequency than before ${ }^{9}$,

- the problem of crisis situations occurring in the electrical energy industry and an appropriate approach to it, in the sphere of a crisis management is a new issue, which was revealed at the moment

\footnotetext{
${ }^{9}$ The cause of it is outdated apparatus and automatics directing the work of power units. It is also a result of outdated technologies used in power plants, unmodernized distribution stations and a shortage of financial means for new grid and productive investments.
} 
of the biggest grid breakdowns, observed in the last ten years both in the world and in Poland,

- classical systems of "protection in the event of a crisis situation occurrence", in the light of the contemporary reality, are out of date and are not relevant to the quickly changing circumstances ${ }^{10}$,

- there is a shortage of scientific publications on the prediction of crisis situations with regard to classical "coal-fired power plants",

- the problem of the prediction of crisis situations in baseload power plants provokes a great interest among managerial personnel and in professional engineering environments of the electrical energy branch,

- up to the present time, no scientific method of management has been elaborated, which would identify and diagnose symptoms of a future crisis in a professional baseload power plant, and which would concern making decisions in the danger fields discussed in the article.

In the light of the above studies there appears to be an unsolved serious problem for power plants:

"How, in the light of measures undertaken, aimed at securing the electrical energy safety of the country, at certain limitation, may a crisis situation be predicted and what decisions should be made on the operational level to avoid the effects of a future crisis?".

\section{The usage of artificial intelligence methods to predict a crisis situation in an electrical en- ergy utility}

\subsection{Concept of the problem solving}

The solution to such formed research problem is a management method based on predicting a crisis situation in a power plant, which uses process modeling

\footnotetext{
${ }^{10}$ As an example, we may give a set of procedures in the event of a crisis situation presented on page 104 in Instruction on Transmission Grid Movement and Exploitation (elaborated by Polish Electrical energy Grids Joint-stock Company). Item 5.2.5.2 speaks about the procedure in the situation of the system breakdown, as follows:"...work of turbogenerators should be kept according to the strictly defined procedure of The Independent System Operator of telephone orders or within the socalled tele-orders system". As the reality showed, the tele-orders system during the breakdown of 26 June 2006 appeared completely useless and even erroneous for the personnel of power units operation in some power plants (Kozienice, Połaniec, Bełchatów)
}

based on the technique of the artificial neural network. This method contains an important feature of the neural network, which is an ability to predict time series, which found an application in predicting overloading, within which critical overloadings that have a destructive influence on the work of turbogenerators. It should be emphasised that the prediction of future values of the critical power is a significant factor of the process of decision-making by the engineer personnel, in the situation of a coming crisis.

In the effect of applied integrated techniques of the artificial intelligence, appropriate neural models were built, which were predictors of a crisis situation in a power plant. The proposed method allows the engineer personnel to make certain preventive organization actions in a baseload power plant, where a crisis situation is generated by three types of danger:

- overloading of a turbogenerator resulting in a disorderly close-down of the power unit,

- lack of technical-economic data transmission, essential to implement business processes in a utility,

- modification of business data.

The starting point to create the method was to specify the key business areas of the utility covered by the effects of the above mentioned dangers and to gather essential measurement data, which are important for the examined phenomena. Such actions allowed on the implementation of the method into the information architecture of a power plant.

This structure consists of three basic levels:

- the level of information gain,

- the level of information processing,

- the level of making decisions by the administration on the basis of the processed information.

On the level of information processing, with the use of inner LAN in a power plant, the data of the work of the turbosets are transmitted through the Intranet network or special dedicated channels to the main server of the system, where decisions are made, regarding the work and functioning of the power units in a power plant. 


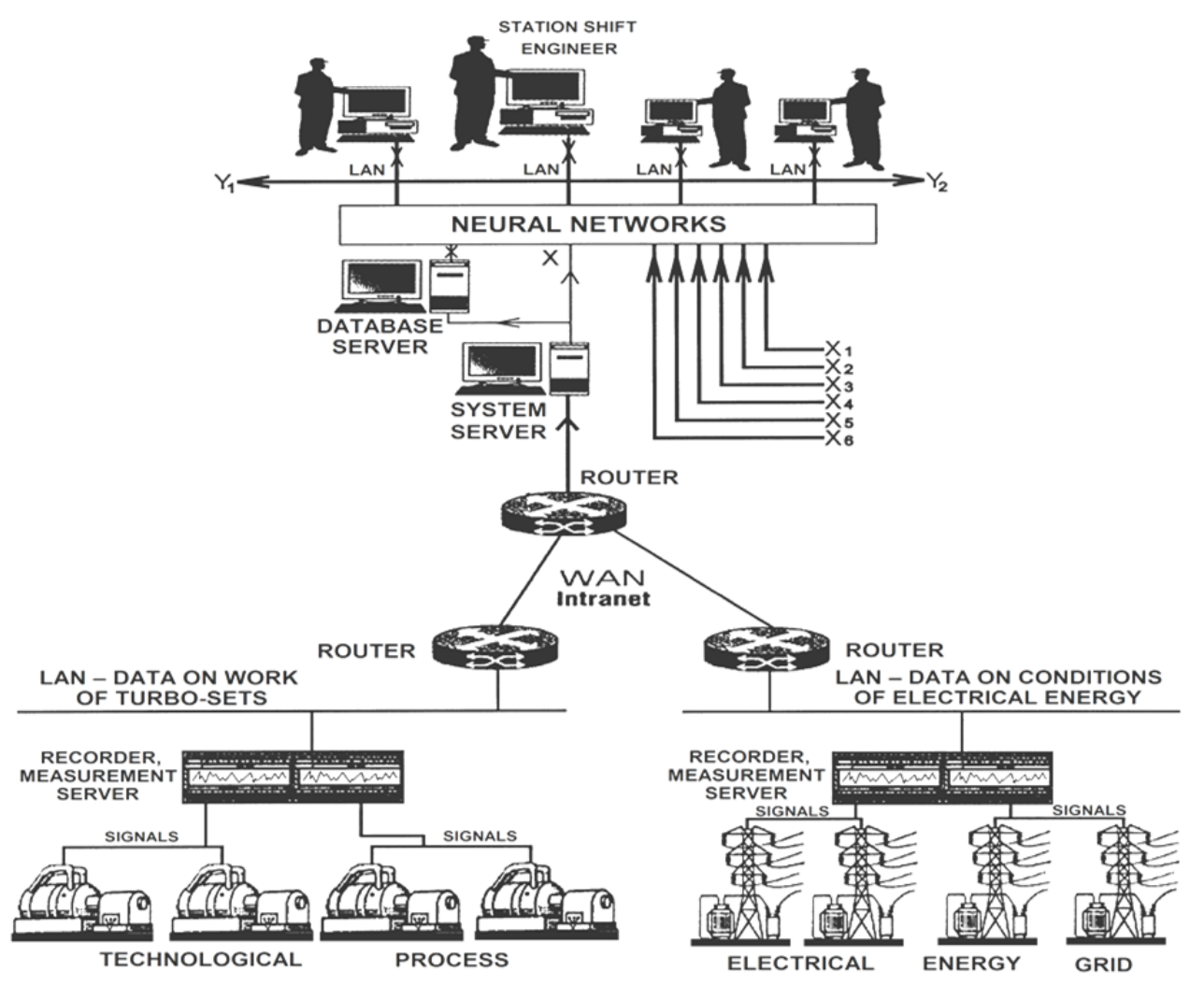

Figure 7. Implementation of the management method, used to predict a crisis situation, into the architecture of the information system of a power plant

(source: self study)

Through the medium of the Intranet network or dedicated telecommunication channels, the server also receives technical data on the condition of the power grid as well as the data concerning the demand on electric power from electrical energy customers. These are data with a great significance to plan the work of turbosets units responsible for generating power and supplying it to the whole electrical energy system.

The values $\mathrm{X}_{1}, \ldots \mathrm{X}_{6}$ are the information delivered to the input of the neural network from the environment, which is really important for the administration to make decisions referring to the functioning of the system. All the information in the form of numerical sequences goes to the level, where it is analysed and processed by neural networks. The information in the form of files with data is gathered and saved on a special server - database, which plays an important part as it is the source of the training data used to teach the neural networks. The information processed by the neural network is transmitted through LAN directly to the management personnel responsible for making decisions. This information may be accepted by the administration or rejected.
The accepted information is used to make particular decisions having an essential meaning for further functioning of the system, which was marked in the diagram as the input data $Y_{1}$ and $Y_{2}$ (responses). If the management personnel do not accept the signals directed from the level processing information, these signals are directed to another analysis (e.g. further search for optimal solutions) or they are totally rejected as unimportant to make a decision. In this case, the neural network fulfils a role of "an adviser - expert" basing on the experience (the data from the past) and predicting future events with a high probability of their occurrence.

Finally, it should be added that the transmission of information in the form of numerical data takes place on the basis of the classical TCP/IP protocol and it provides an opportunity of the access to the data saved in the standard form as well as to the measurement data placed in the form of files with a historical character on the FTP server - the database (the so-called "historian server"). 


\subsection{Gaining and selecting the input data}

The basic source of information, on which the research and the method were based, was a collection of approximately 1 million of historic measurement data. These were data concerning net 24-hour production of active power, gathered from POWER UNIT of 500 MW of Power Station „KOZIENICE”. This data was received from the measurement database saved over the period from January 2002 to January 2010. In the light of such a numerous collection of measurement data, there appeared a problem of their redundancy, which especially at the beginning violated the process of the network training. Therefore, an important phase before starting the due research, was a process of preparing relevant data, the so-called pre-processing, consisting of selection, extraction, cleaning, transformation and supplementation of a possible deficiency in the data sequences.

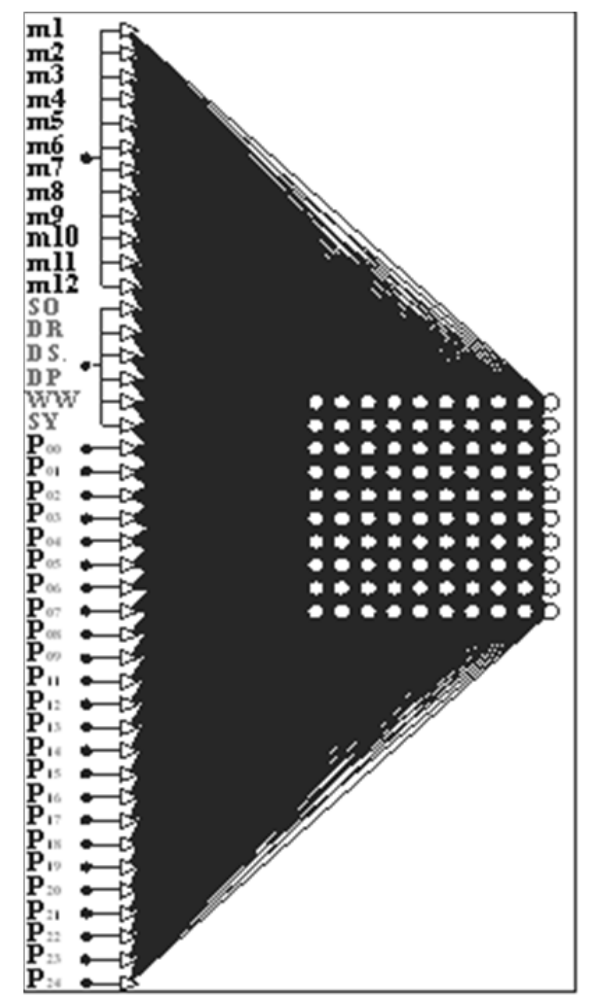

Figure 8. Kohonen model with appropriate power inputs (source: self study)

In this way representative data were prepared, which manifested specific crisis situations, and owing to it an extraction of factors responsible for the crisis situations was done. In this way input variables, being essential to build a neural model, were specified.

The basic input variables were variables with quantitative and qualitative characters. The power input vector contained variables specifying the month, the particular day of the week as well as the variable specifying the active power produced by a power plant within a given measuring hour - $h$. It became essential to apply a binary coding (markering 0 or 1 ) of each of from $n 1$ to $n$ dimensions of the input vector. These actions led finally to the creation of a reliable Kohonen map, in which an appropriate profile of $24 \mathrm{~h}$ turbogenerator overloading was assigned to each network cluster.

Supplementary data, having a significant meaning for a map created in this way, consisted of endogenous variables with a categorized character, to which particular dimensions of the input vector were assigned. Previously mentioned "markering" of the binary type of appropriate inputs of the neural network was applied to these input variables.

The dimensions of Kohonen map were specified arbitrarily through experiments, with consideration of the special network abilities to make generalization. In this way a risk map came into being, created by the selforganizing map of Kohonen features.

A set of pattern vectors was obtained, which characterized $24 \mathrm{~h}$ overloading profiles of a turbogenerator of a power unit with the capacity of $500 \mathrm{MW}$, in different states and conditions of the environment (with consideration of the work of a power unit in the conditions of interruptions and an occurrence of a crisis situation). A specified work condition of a turbogererator (the socalled profile of $24 \mathrm{~h}$ overloading of a turbogenerator) was assigned to each network cluster. The areas of the so-called forbidden work were obtained on the map, i.e. work being generated by crisis situations.

An application of the neural model (Kohonen map) allowed on the comparison process of the pattern vectors (profile overloadings) with the control vector, being a profile vector built on the basis of the last correct transmission of the data essential to implement the business processes. An assignment of the entire 24h profile of a turbogenerator to an appropriate neural network cluster is done in this process.

The content of each of the model sets undergoes a comparison process by Kohonen network with the real set of data, which represents the current work condition of the device with the above mentioned control vector. As a result of the comparison of the pattern set with the real set, one of the neurons is activated (the socalled neuron "the winner"). This takes place when appropriate characteristics are "fit" to each other. An analysis of the location of the work points on the 
risk map allows the management personnel to control the conditions which may lead to a crisis situation (especially an overloading of a power unit).

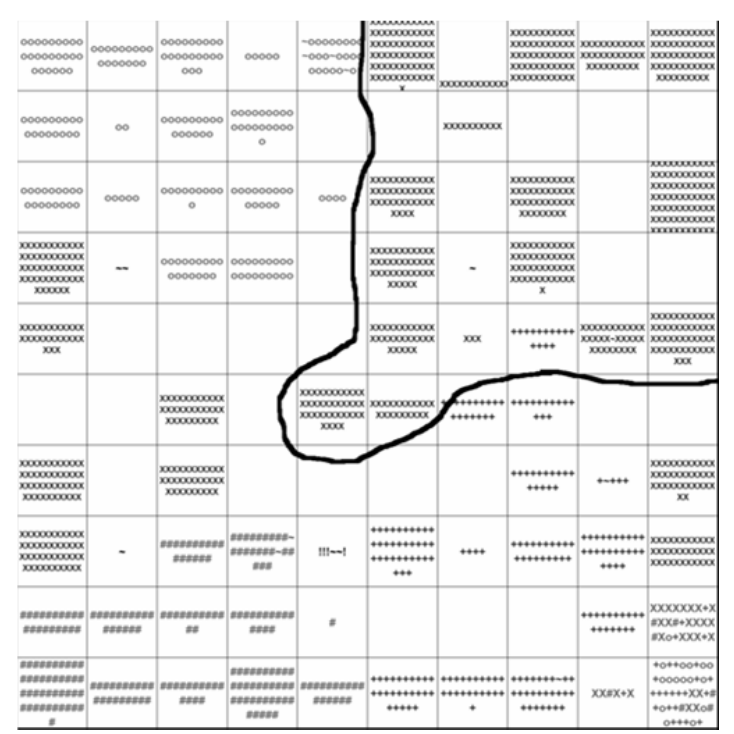

Figure 9. Set of model vectors in the form of Kohonen map (risk map), with the marked area of forbidden work of a turbogenerator (source: self study)

In the Figure 10 points 1, 2, 3 indicate the localization of profile vectors in clusters of the map, respectively for $24 \mathrm{~h}$ overloading in time intervals D-1, D-2, D-3, the existed situation and the graph direction indicate a possibility of work in the forbidden area.

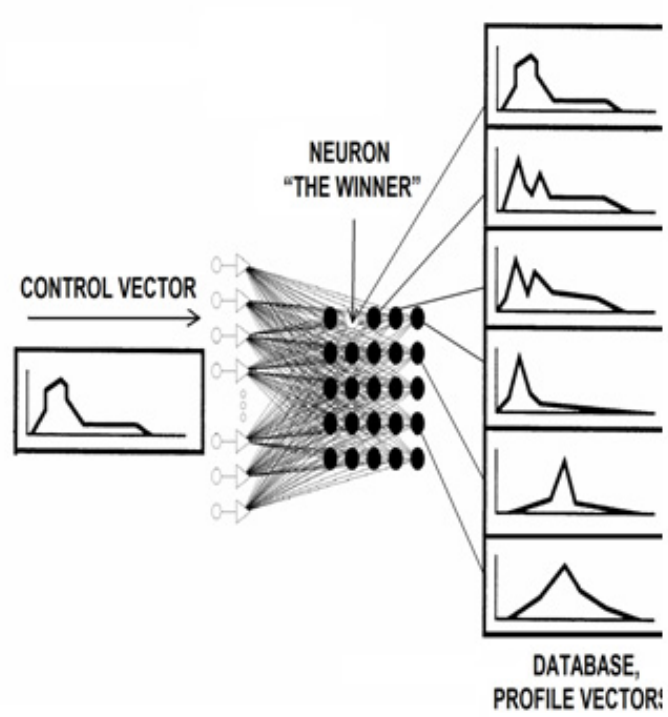

In this phase of the method, correctness verification of the transmission stream of the data takes place as well as detection of the modified data (the control vector does not fit any pattern characteristics). In this way a crisis situation in a power plant is eliminated, which would be caused by a purposeful modification of technical-economic data essential to implement business processes. In this case Kohonen network plays the role of a data discriminator.

The next important phase of the experiment was to build neural models, predictors of critical overloadings of a turbogenerator. Three types of the neural network were tested with the use of different forms of the input vector and different structures and methods of teaching the network (MLP, RBF, GRNN). The input vector contained 16 variables with changing quantitative and qualitative characters. The input variable took a quantitative value and returned the result of a time series prognosis one-hour in advance $(\mathrm{h}+1)$.

However, the research assumption was that the network would generate a prognosis at the output 24 hours in advance. So it should be assumed that prognosing the next values of the prognosed time series $(\mathrm{h}+2)$, $(\mathrm{h}+3) \ldots$ to $(\mathrm{h}+24)$ is done through an introduction of the values prognosed in the previous steps to the network inputs.

Figure 10. The activation of networks with the help of the control vector - comparison process, where the profile vector is being assigned to an appropriate network cluster - the risk map 


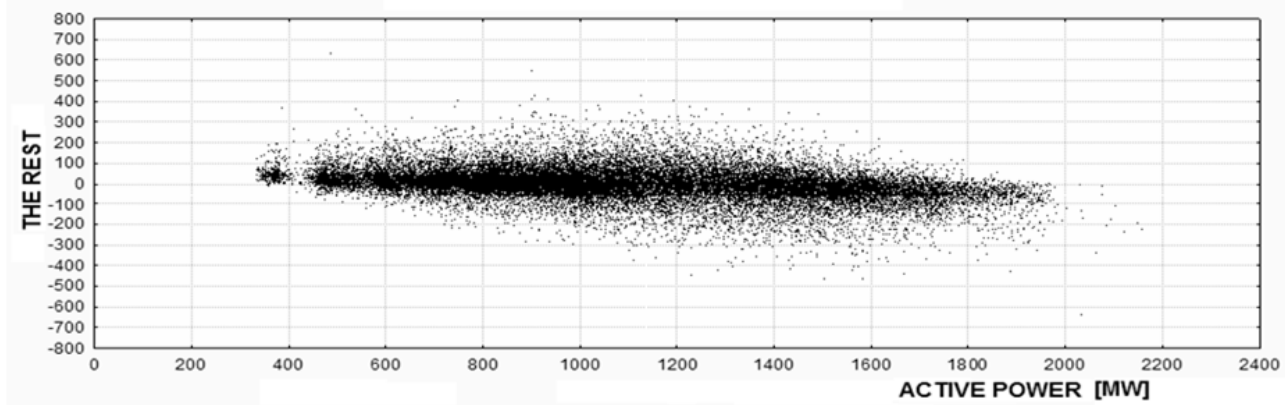

Figure 11. Diagram of the rests for RBF network - the best built model with the parameters of: aberration quotient of 0,19 correlation of 0,98 MAPE error of $4,7 \%$

(source: self study)

24 digits, being a series of the prognosed values of overloading in specified hours, were obtained at the output. It should be emphasised here that redundancy in the dimensions of the input vector increased the number of weighs in the network, which affected the process of teaching the network.

As the research showed, this phase of the method contributes to the quality of the prognosis to the greatest extent. In the light of the studies and experiments with the use of the artificial neural networks, we may say, that the most important factor deciding upon the quality of the neural models (the smallest errors, time of teaching, a number of iterations necessary to train the network) is the quality of the data used to the process of teaching the network. Another important factor is an appropriate representative trial of the teaching data (redundancy specified arbitrarily). Therefore it was necessary to prepare an appropriately numerous set of the redundant data. In this way a broad spectrum of the teaching data was obtained, which contained multiple repetitions of similar patterns and which manifested specified phenomena, within which the symptoms of a crisis situation.

In the final phase of the method, a critical turbogenerator overloading started to be prognosed with the use of neural models generating a crisis situation.

It is worth emphasising that the elimination of untypical variables from the teaching set improved the model quality (decrease in MAPE error to approximately $2,5 \%$ ), yet on the other hand, there was an increasing danger of a loss of the complete spectrum of the teaching data which manifested different conditions of the work of a power unit, within which the symptoms of a crisis situation. Therefore the error on the level of $4,7 \%$ was recognized as satisfactory.

\section{Summary and final conclusions}

Application of the anti-crisis actions with the use of the discussed method allowed a decrease of $82 \%$ of the losses, which a power plant would bear in the effect of no application of any preventive actions. These losses, first of all, result from unbalanced demand and supply of electrical energy. A choice of artificial neural networks as a research tool was dictated, in the first place, by all the possibilities, which these "sophisticated techniques" entail. Because of non-linearity of dependencies, multidimensional input vectors, multiple character of some relations between exogenous and endogenous variables, a lack of bases to linear approximation of phenomena and processes as it takes place in case of process modelling in the electrical energy industry, application of neural networks that can map non-linear dependencies is deeply justified. Accepting such an assumption and its application in the presented management method led to a solution of the research problem mentioned previously.

In this method a very important feature of neural networks was used, which is the ability to predict time series data, which found its use in prediction of overloadings, within which, overloadings of critical turbogenerators. Prediction of future values of power is a significant factor in the decision-making process preventing crisis situations. This method is an alternative one when an electrical energy utility finds itself in a situation of impending crisis. It allows the engineer personnel (Station Shift Engineer) to undertake a lot of organization actions, among which, they may use an early switching-off of the power unit, even being in the state of the so-called "cold reserve". As the research - movement trials showed- the average time required to put such a power unit into full operation amounts only to 40 minutes. The second important 
organization action, which may be undertaken by the management personnel, is a simultaneous switching-on of another, additional relieving power unit for the time of a crisis situation, which as the previous research shows, could be predicted with the use of the proposed method. The third important solution, which may be applied owing to this method, is relieving a power unit of the parent power plant through pre-planned putting an additional power unit in another power plant into operation (planned switching-on of the spinning reserve).

The research conducted with the use of the artificial intelligence techniques appeared to be very promising. On the basis of the research and experiments conducted an application in the language $\mathrm{C}++$ has been created, with the name ACM-2010, and it has been implemented in the real conditions of the work of power plants. It will allow the management personnel to select specified organization actions preventing a crisis situation in an electrical energy utility.

The authors hope that laborious long-term research will contribute, at least to a little degree, to overturn a myth existing in engineering environments, which says that the science and the industry have not elaborated satisfactory methods of appropriate cooperation yet.

\section{$7 \quad$ References}

[1] Barton R.M. - Crisis Management. Oxford Press Publishers, Oxford 1993.

[2] Górzyński J., Urbaniec K. - Wytwarzanie i użytkowanie energii $w$ przemyśle. Oficyna Wydawnicza Politechniki Warszawskiej, Warszawa 2000.

[3] Helt P., Parol M., Piotrowski P.- Metody sztucznej inteligencji $w$ elektroenergetyce. Oficyna Wydawnicza Politechniki Warszawskiej, Warszawa 2000 .

[4] Kalyvas E. - Using neural networks and genetic algorithms to predict stock market returns. Department Of Information technology Science, University Of Manchester, Manchester 2001.

[5] Lelątko P., Michalski D. - Zarzqdzanie ryzykiem na rynku energii elektrycznej. Instytut Doskonalenia Wiedzy o Rynku Energii, Warszawa 2004, pp.167246.
[6] Maj K. - Informatyka w energetyce-przyklady zastosowań i funkcjonowania systemów informatycznych w wybranych segmentach Rynku Energii Elektrycznej $w$ Polsce. Zeszyty Naukowe Nauki Ekonomiczne Nr 33, Politechnika Świętokrzyska, Kielce 2005.

[7] Maj K. - Możliwości zastosowania sieci neuronowych $w$ przewidywaniu sytuacji kryzysowej w przedsiębiorstwie elektroenergetycznym. Zeszyty Naukowe Nauki Ekonomiczne Nr 35, Politechnika Świętokrzyska, Kielce 2007.

[8] Maj K. - Możliwości zastosowania sieci neuronowych w Systemach Wczesnego Ostrzegania - jako narzędzia wspomagajacego procesy zarzqdzania $w$ energetyce. Zeszyty Naukowe Nauki Ekonomiczne Nr 34, Politechnika Świętokrzyska, Kielce 2006.

[9] Malko J. - Wybrane zagadnienia prognozowania $w$ elektroenergetyce. Oficyna Wydawnicza Politechniki Wrocławskiej, Wrocław 1995.

[10] Mitchell M. - An introduction to genetic algorithms. MIT Press, Cambridge 1997.

[11] Oldcorn R. - Management. London MacMillan 1989.

[12] Osowski S. - Sieci neuronowe do przetwarzania informacji. Oficyna Wydawnicza Politechniki Warszawskiej, Warszawa 2000.

[13] Siwek K. - Prognozowanie obciażeń w systemie elektroenergetycznym przy wykorzystaniu sztucznych sieci neuronowych. rozprawa doktorska, Wydział Elektryczny Politechniki Warszawskiej, Warszawa 2001.

[14] Weron A. - Giełda Electrical - strategie zarzadzania ryzykiem. CIRE, Wrocław 2000.

[15] Zerka M. - Mechanizmy rynkowe $w$ elektroenergetyce - zagadnienia wybrane. Instytut Doskonalenia Wiedzy o Rynku Energii, Warszawa 2001.

[16] Raport Końcowy z prac Zespołu ds. Analizy Zakłóceń w Systemie Elektro-energetycznym w 2006 roku. Departament Energetyki Ministerstwa Gospodarki, Warszawa 2006.

[17] Raport na temat stanu zagrożenia ciagłości pracy krajowego systemu elektro-energetycznego $w$ Polsce. Departament Usług Operatorskich, Polskie Sieci Elektro-energetyczne S.A., Warszawa 2006. 